\title{
SISTEM MONITORING PENGGUNAAN DEBIT AIR KONSUMEN DI PERUSAHAAN DAERAH AIR MINUM SECARA REAL TIME BERBASIS ARDUINO UNO
}

\author{
Nidar Nadrotan Naim ${ }^{1}$, Imam Taufiqurrahman ${ }^{2}$ \\ Universitas Siliwangi (Teknik Elektro, Universitas Siliwangi, Tasikmalaya, Indonesia) \\ email: (Nidar.nns@gmail.com)
}

\begin{abstract}
PDAM or regional water supply company is one of the regional-owned business units engaged in the distribution of clean water to the general public. Given the increasing use of clean water for human life, the PDAM is required to meet the needs of clean water for the general public. It is important to know the use of water discharge in homes and industries, but in reality, the current PDAM water meter readings are still difficult for consumers to read, because they still have to be converted from cubic meters to prices. With the analog reading system that is still in use today, PDAM officials also still record water usage data by visiting each house or industry. The purpose of this research is to design and create a real-time arduino uno-based consumer water debit monitoring system to make it easier for consumers to read PDAM water usage, billing rates, time, date in real time and flexibly. The design and manufacture of a real-time arduino uno-based consumer water flow monitoring system uses the YF-S201 water sensor, Arduino Uno, RTC DS1307, Icomsat Sim900 GPRS Shield Module, 16x2 LCD, I2C and buzzer. The test results show that the components are working according to the Arduino Uno microcontroller command. YF-S201 waterflow sensor is able to read the amount of water consumption of PDAM consumers with an average deviation of $0.84 \%$. The Icomsat Sim900 GPRS Shield module manages to send data 7 times to the thingspeak webserver as expected and without connection interruptions. Then the PDAM officer can also monitor water usage in real time remotely through the thingspeak flatfrom web server without the need to visit each PDAM customer.
\end{abstract}

Keywords: PDAM, Arduino Uno, YF-S201 Waterflow Sensor, Icomsat Sim900, Thingspeak, Real time.

Abstrak

PDAM atau perusahaan daerah air minum merupakan salah satu unit usaha milik daerah yang bergerak dalam distribusi air bersih bagi masyarakat umum. Mengingat semakin meningkatnya penggunaan air bersih untuk kehidupan manusia, maka PDAM dituntut untuk memenuhi kebutuhan air bersih bagi masyarakat umum. Pentingnya untuk mengetahui penggunaan debit air dalam rumah maupun industri, namun pada kenyataanya, pembacaan meter air PDAM saat ini masih sulit dibaca oleh konsumen, karena masih harus dikonversi dari meter kubik hingga menjadi harga. Dengan sistem pembacaan analog yang masih digunakan saat ini, petugas PDAM juga masih mencatat data penggunaan air dengan cara mengunjungi ke setiap rumah. Tujuan penelitian ini adalah merancang dan membuat sistem monitoring penggunaan debit air konsumen secara real rime berbasi arduino uno untuk memudahkan konsumen membaca penggunaan air PDAM, tarif tagihan, waktu, tanggal secara real time dan fleksibel. Perancangan dan pembuatan sistem monitoring penggunaan debit air konsumen secara real rime berbasis arduino uno ini menggunakan waterlflow sensor YF-S201, Arduino Uno, RTC DS1307, Modul Icomsat Sim900 GPRS Shield, LCD 16x2, I2C dan buzzer. Dari hasil pengujian menunjukan bahwa komponen-komponen sudah bekerja sesuai perintah mikrokontroler arduino uno. Waterflow sensor YF-S201 mampu membaca jumlah konsumsi air konsumen PDAM dengan rata-rata penyimpangan sebesar 0,84\%. Modul Icomsat Sim900 GPRS Shield berhasil mengirim data sebanyak 7 kali ke webserver thingspeak sesuai dengan harapan dan tanpa adanya gangguan koneksi. Kemudian petugas PDAM juga bisa memonitoring penggunaan air secara real time dari jarak jauh melalui flatfrom webserver thingspeak tanpa perlu mengujungi ke setiap konsumen PDAM.

Kata Kunci: PDAM, Arduino Uno, Waterflow Sensor YF-S201, Icomsat Sim900, Thingspeak, Real time.

\section{PENDAHULUAN}

Air bersih merupakan salah satu kebutuhan pokok masyarakat, sumber air bersih bisa diperoleh dari air hujan, air tanah, mata air dan air Perusahaan Daerah Air Minum (PDAM). Air sangat berguna dalam kehidupan sehari hari bagi manusia karena dapat digunakan untuk minum, mencuci dan mandi. Dalam pemakaiannya manusia tidak pernah memperhatikan berapa jumlah debit air yang telah digunakan, inilah yang menjadi persoalan utama karena tidak bisa memonitoring dan membaca jumlah pemakaian air tersebut. Selain masalah tersebut pihak penyedia air atau PDAM mengalami kendala saat pengambilan data ke setiap konsumen PDAM yang harus mengunjungi ke setiap rumah. Hal tersebut tidak efesien dan memakan banyak waktu untuk mengambil data tersebut.

Berdasarkan uraian di atas maka dibutuhkan suatu alat yang dapat memonitoring debit air secara real time dengan menggunakan alat yang akan dibuat dalam penelitian ini, alat tesebut dapat membaca volume air dan tegangan baterai yang nantinya akan ditampilkan secara langsung pada display di lokasi pengukuran maupun di luar lokasi. Pada apenelitian sebelumnya telah dibuat Sistem Pembacaan Jumlah Konsumsi Air Pelanggan PDAM Berbasis Mikrokontroler ATMEGA328 Dilengkapi SMS [1], dalam penelitian tersebut pengguna mendapatkan report melalui SMS. Pengembangan pada penelitian ini Konsumen dapat mengetahui jumlah pemakaian air dalam sehari-hari dengan aplikasi android melalui smart phone, PC maupun pada alat monitoring. Seperti terdapat pada penelitian [2] dilakukan system monitoring menggunakan IoT yang memudahkan pelanggan untuk membaca dan mengontrol pemakaian air. Selain itu PDAM juga dapat memonitoring konsumsi air konsumen secara real time melalui platfrom IoT webserver Thingspeak tanpa perlu mengunjungi konsumen PDAM. Hal lebih efesien dan efektif dalam pengambilan data.

\section{KAJIAN PUSTAKA}

A. Air Minum

Air minum merupakan salah satu sumber daya alam yang diperlukan untuk kehidupan manusia, bahkan oleh semua makhluk hidup. Seluruh organisme yang ada dibumi 
sebagian besar tersusun dari air dan hidup dalam lingkungan yang didominasi oleh air. Air merupakan suatu sarana utama untuk meningkatkan derajat kesehatan masyarakat.

\section{B. PDAM ( Perusahaan Daerah Air Minum )}

PDAM merupakan Badan usaha milik daerah yang masuk dalam kategori penyelenggara pelayanan yang bersifat profit dengan tugasnya memberikan pelayanan air bersih kepada warga masyarakat pada suatu daerah. PDAM sebagai salah satu instansi pemerintah yang berbentuk BUMD memiliki jenis pelayanan yang termasuk dalam kelompok pelayanan barang yaitu pelayanan yang menghasilkan berbagai bentuk/jenis barang dalam hal ini adalah penyediaan air bersih.

\section{Meter Air Konvensional PDAM}

Meter air merupakan alat untuk mengukur banyaknya aliran air secara terus menerus melalui sistem kerja peralatan yang dilengkapi dengan unit sensor, unit penghitung, dan unit indikator pengukur untuk menyatakan volume air yang lewat. Sehingga meter air merupakan alat yang digunakan untuk menghitung volume air yang di distribusikan oleh PDAM (Perusahaan Daerah Air Minum) ke pelanggan, sehingga dapat ditentukan jumlah biaya yang harus dibayar.

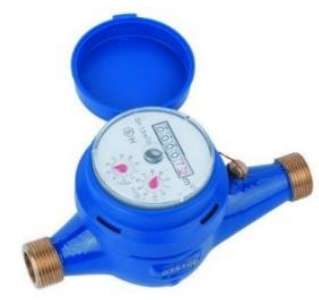

Gbr 1. Meter Air

\section{Fluida}

Aliran suatu fluida didefinisikan sebagai volume fluida yang melewati daerah penampang tertentu dalam per satuan waktu. Istilah cross sectional area hanyalah istilah yang sering digunakan untuk menggambarkan area di mana sesuatu mengalir.

Laju aliran volume mengukur jumlah volume yang melewati area per satuan waktu, persamaan untuk laju aliran volume terlihat seperti ini:

\section{$\mathrm{Q}=\mathrm{V} / \mathrm{t}$}

Dimana :

$\mathrm{Q}=$ Debit Aliran (m3/s)

$\mathrm{V}=$ volume $(\mathrm{m} 3)$

$\mathrm{t}=$ selang waktu $(\mathrm{s})$

\section{E. IOT ( Internet Of Things)}

Internet of Things adalah suatu konsep dimana objek tertentu punya kemampuan untuk mentransfer data lewat jaringan tanpa memerlukan adanya interaksi dari manusia ke manusia ataupun dari manusia ke perangkat computer.

\section{F. Thingspeak}

ThingSpeak merupakan sebuah layanan internet yang menyediakan layanan untuk pengaplikasian "Internet of Things". Seperti pada penelitian [3] yang menggunakan thingspeak sebagai sistem monitoring tangki SPBU. Thingspeak merupakan layanan yang berisi aplikasi dan API yang bersifat open source untuk menyimpan dan mengambil data dari berbagai perangkat yang menggunakan HTTP (Hypertext Transfer Protocol) melalui Internet atau melalui LAN (Local Area Network). Dengan menggunakan
ThingSpeak, seseorang dapat membuat aplikasi logging sensor, aplikasi pelacakan lokasi, dan jaringan sosial dari segala sesuatu yang terhubung ke internet dengan pembaruan status.

\section{METODE}

Tahap perancangan terdiri dari dua bagian yaitu perancangan Hardware dan software. Dengan merujuk pada arsitektur system dan blok diagram system yang telah dirancang.

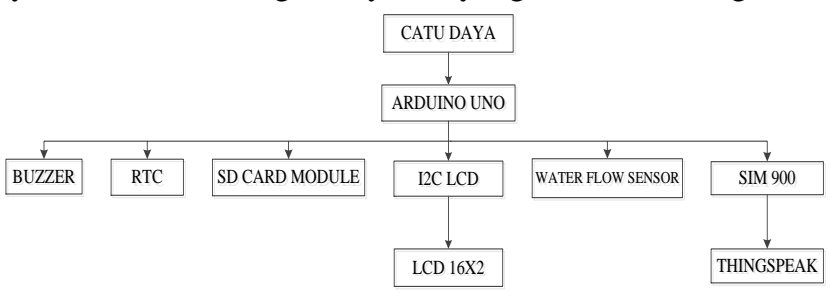

Arsitektur Sistem

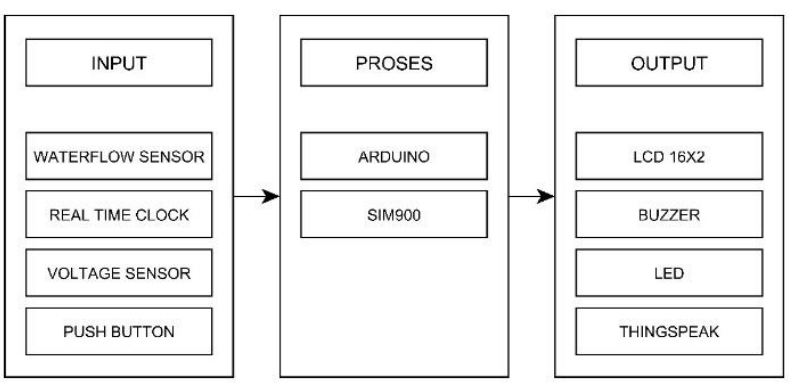

Gbr 2. Blok Diagram Sistem

\section{A. Perancangan Hardware}

Pada tahap perancangan hardware dilakukan juga pemilihan spesifikasi untuk komponen alat ini. Pemilihan spesifikasi didasarkan pada kebutuhan lapangan yang telah di pertimbangkan.

1) Solar Cell

Sel Surya atau Solar Cell adalah suatu perangkat atau komponen yang dapat mengubah energi cahaya matahari menjadi energi listrik dengan menggunakan prinsip efek Photovoltaic. Yang dimaksud dengan Efek Photovoltaic adalah suatu fenomena dimana munculnya tegangan listrik karena adanya hubungan atau kontak dua elektroda yang dihubungkan dengan sistem padatan atau cairan saat mendapatkan energi cahaya.

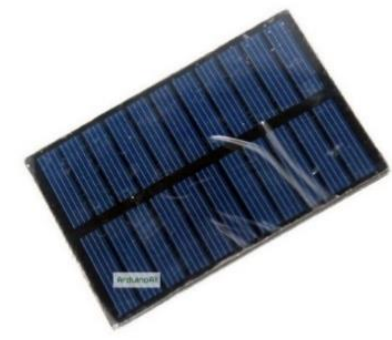

Gbr 3. Solar Cell

Tbl 1. Spesifikasi Solar Cell

\begin{tabular}{|c|l|l|}
\hline No & Spesifikasi & Solar Cell \\
\hline 1 & Tegangan Max & 6 volt \\
\hline 2 & Daya Max & 1 Watt \\
\hline 3 & Arus Max & $200 \mathrm{~mA}$ \\
\hline 4 & Ukuran & $11 \times 6 \times 0,25$ \\
\hline
\end{tabular}

2) Baterai Lithium Polymer

Di dalam baterai ini, ion litium bergerak dari elektroda negatif ke elektroda positif saat dilepaskan, dan kembali 
saat diisi ulang. Baterai Li-ion memakai senyawa litium interkalasi sebagai bahan elektrodanya, berbeda dengan litium metalik yang dipakai di baterai litium non-isi ulang. Baterai ion litium umumnya dijumpai pada barang-barang elektronik konsumen. Baterai ini merupakan jenis baterai isi ulang yang paling populer untuk peralatan elektronik portabel, karena memiliki salah satu kepadatan energi terbaik, tanpa efek memori, dan mengalami kehilangan isi yang lambat saat tidak digunakan [4].

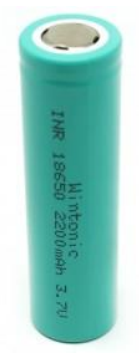

Gbr 4. Baterai Lithium

Tb1 2. Spesifikasi Baterai Lithium

\begin{tabular}{|l|l|l|}
\hline No & Spesifikasi & Baterai Lithium \\
\hline 1 & Cell model & HM-18650 2200mAh; \\
\hline 2 & Brand: & Hame \\
\hline 3 & Rated capacity & $2200 \mathrm{mAh} ;$ \\
\hline 4 & Rated voltage & $3.7 \mathrm{~V} ;$ \\
\hline 5 & Size & $18.4 * 65.2 \mathrm{~mm} ;$ \\
\hline 6 & Impedance & $\leq 65 \mathrm{~m} \Omega ;$ \\
\hline 7 & Weight & $44 \mathrm{~g} ;$ \\
\hline 8 & Charge cut-off voltage & $4.2 \mathrm{~V} ;$ \\
\hline 9 & Discharge cut-off voltage & $3.0 \mathrm{~V} ;$ \\
\hline 10 & Charge temperature & $0 \sim 45$ \\
\hline 11 & Discharge temperature & $-20 \sim+60$ \\
\hline 12 & Charge current & standard $430 \mathrm{~mA}$, fast $1500 \mathrm{~mA} ;$ \\
\hline 13 & Charge time & standard $3 \mathrm{hrs,} \mathrm{fast} 2.5 \mathrm{hrs} ;$ \\
\hline 14 & Discharge current & standard $320 \mathrm{~mA}$, max $2500 \mathrm{~mA} ;$ \\
\hline
\end{tabular}

3) Perancangan

Setelah dilakukan pengumpulan bahan-bahan yang dibutuhkan dalam perancangan maka dilakukan mendesain box dan perakitan komponen sesuai dengan rancangan sistem yang telah dibuat. Berikut ini adalah hasil dari perancangan sistem monitoring debit air konsumsen secara real time berbasis arduino yang telah dibuat.

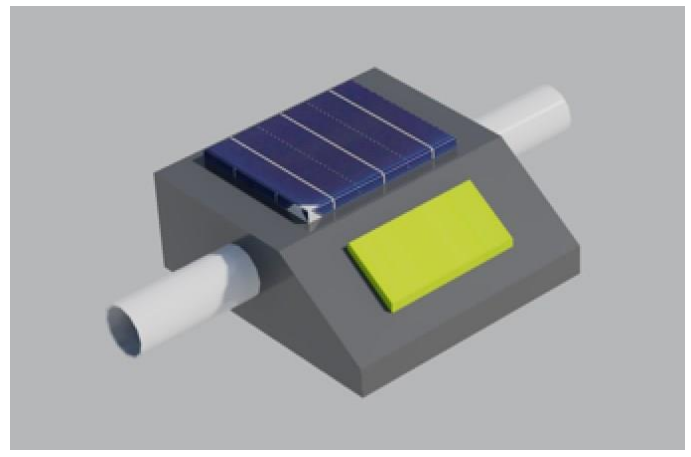

Gbr 5. Pemodelan Box Sistem Monitoring Debit Air

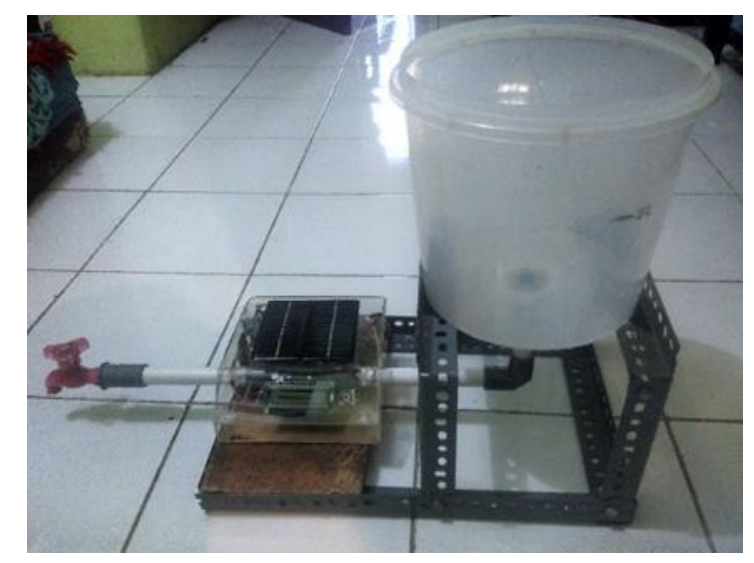

Gbr 6.

Realisasi Alat Monitoring Debit Air Konsumsen Secara Real Time

\section{B. Perancangan Software}

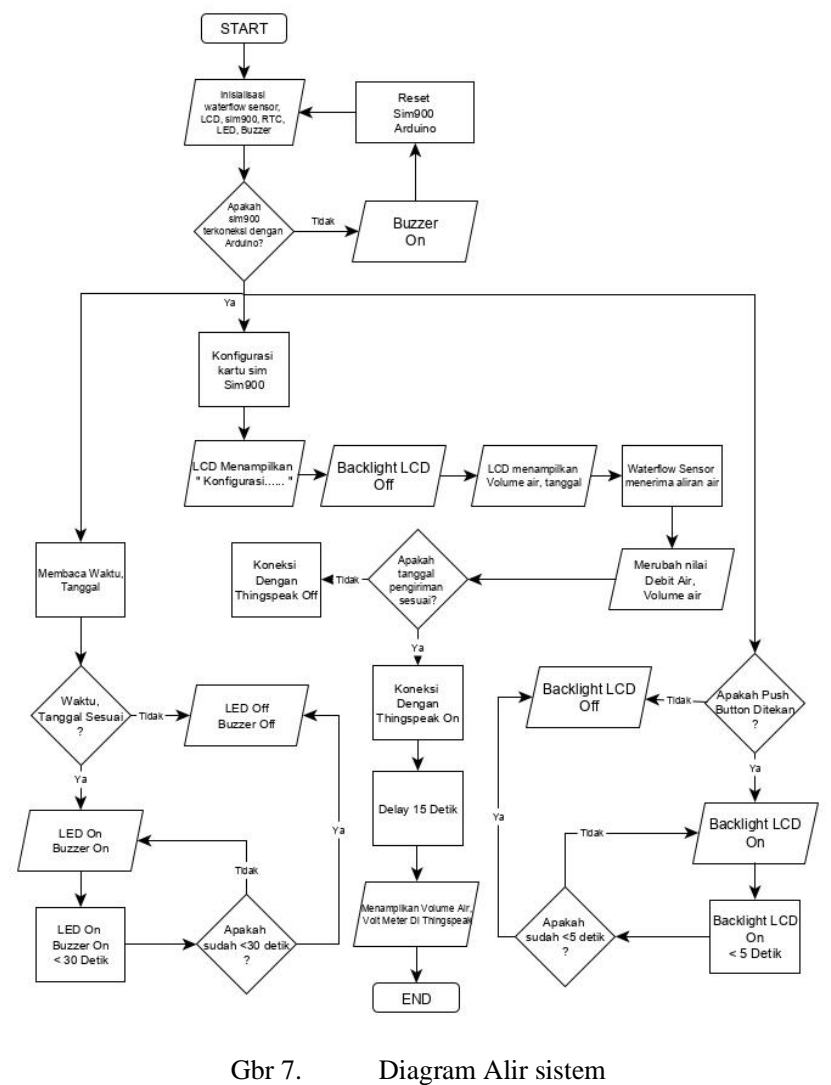

Sistem pertama dinyalakan, pertama-tama melakukan proses inisialisasi bagian-bagian dalam sistem Monitoring tersebut seperti RTC, Waterflow Sensor, Led, Buzzer, LCD dan SIM900. Arduino tersebut akan mengenali 4 jenis input yang berbeda. Sensor waterflow sensor untuk mengukur aliran air yang mengalir, RTC digunakan untuk pewaktu digital saat air mengalir, Voltage Sensor digunakan untuk mengukur tegangan baterai, Push button digunakan untuk menghidupkan backlight LCD. Setelah itu Arduino uno akan memberi perintah "AT command" kepada SIM900 apakah SIM900 terkoneksi dengan baik dengan arduino uno atau tidak. Jika tidak terkoneksi dengan Arduino, Buzzer akan menyala dan arduino akan mereset ulang program dari awal hingga Arduino menemukan respon "OK".

Setelah menemukan respon "OK" LCD akan menampilkan " Konfigurasi...” bersamaan dengan proses konfigurasi kartu SIM900 hingga selesai. Jika tidak 
menemukan request IP maka arduino akan mereset ulang program dari awal hingga menemukan request IP. Selesai menemukan request IP, Backlight LCD akan mati dan LCD akan menampilkan informasi berupa tanggal dan volume air.

Jika waterflow sensor menerima aliran air maka display LCD akan menampilkan hasil dari pengukuran tersebut yaitu berupa volume air. Ketika waktu RTC pada arduino sesuai dengan waktu yang telah ditentukan di software IDE arduino maka Sim900 akan mengirim data ke webserver thingspeak. Jika waktu yang telah ditentukan melebihi waktu yang telah ditentukan maka SIM900 tidak akan mengirim data ke webserver thingspeak.

Untuk menyalakan backlight LCD, tekan push button selama $10 \mathrm{~ms}$ maka backlight LCD akan menyala selama 5 detik dan setelah itu backlight LCD akan mati. Untuk mereset jumlah volumer air, menyalakan buzzer dan led sebagai pengingat tagihan, maka diperlukan pengaturan tanggal, waktu terlebih dahulu dari software IDE Arduino uno. Jika tanggal dan waktu sesuai dengan Real time clock maka volume air pada LCD akan mereset menjadi 0, buzzer dan led akan menyala selama 30 detik. Jika lebih dari 30 detik maka led, buzzer akan mati.

\section{HASIL DAN PEMBAHASAN}

\section{A. Pengujian Waterflow Sensor}

Pengujian ini dilakukan dengan tujuan untuk mengetahui kemampuan Waterflow Sensor dalam mengukur volume air. Dalam pengujian ini waterflow sensor akan diuji dengan beberapa kali dialiri oleh air, yaitu dengan cara air pada gelas ukur dituangkan kedalam saluran pipa yang terhubung dengan waterflow sensor. Berikut ini adalah hasil proses pengujian waterflow sensor yang telah dialiri oleh air.

\begin{tabular}{ccccc} 
Tbl 3. & \multicolumn{4}{c}{ Pengujian waterflow sensor dengan nilai kalibrasi 5,5 } \\
$\begin{array}{c}\text { No. } \\
\text { Percobaan }\end{array}$ & $\begin{array}{c}\text { Output } \\
\text { Sensor }(\mathbf{m l})\end{array}$ & $\begin{array}{c}\text { Metode Gelas } \\
\text { Ukur }(\mathbf{m l})\end{array}$ & $\begin{array}{c}\text { Selisih } \\
(\mathbf{m l})\end{array}$ & Kalibrasi \\
\hline $\mathbf{1}$ & $564 \mathrm{ml}$ & $500 \mathrm{ml}$ & $64 \mathrm{ml}$ & 5.5 \\
\hline $\mathbf{2}$ & $642 \mathrm{ml}$ & $500 \mathrm{ml}$ & $142 \mathrm{ml}$ & 5.5 \\
\hline $\mathbf{3}$ & $474 \mathrm{ml}$ & $500 \mathrm{ml}$ & $26 \mathrm{ml}$ & 5.5 \\
\hline $\mathbf{4}$ & $552 \mathrm{ml}$ & $500 \mathrm{ml}$ & $52 \mathrm{ml}$ & 5.5 \\
\hline $\mathbf{5}$ & $561 \mathrm{ml}$ & $500 \mathrm{ml}$ & $61 \mathrm{ml}$ & 5.5 \\
\hline $\mathbf{6}$ & $540 \mathrm{ml}$ & $500 \mathrm{ml}$ & $40 \mathrm{ml}$ & 5.5 \\
\hline $\mathbf{7}$ & $522 \mathrm{ml}$ & $500 \mathrm{ml}$ & $22 \mathrm{ml}$ & 5.5 \\
\hline $\mathbf{8}$ & $534 \mathrm{ml}$ & $500 \mathrm{ml}$ & $34 \mathrm{ml}$ & 5.5 \\
\hline $\mathbf{9}$ & $540 \mathrm{ml}$ & $500 \mathrm{ml}$ & $40 \mathrm{ml}$ & 5.5 \\
\hline $\mathbf{1 0}$ & $549 \mathrm{ml}$ & $500 \mathrm{ml}$ & $49 \mathrm{ml}$ & 5.5 \\
\hline Total & $5478 \mathrm{ml}$ & & $530 \mathrm{ml}$ & \\
\hline
\end{tabular}

Berdasarkan perbandingan hasil pengujian diatas, maka dibuatlah grafik dari nilai hasil penghujian tersebut.

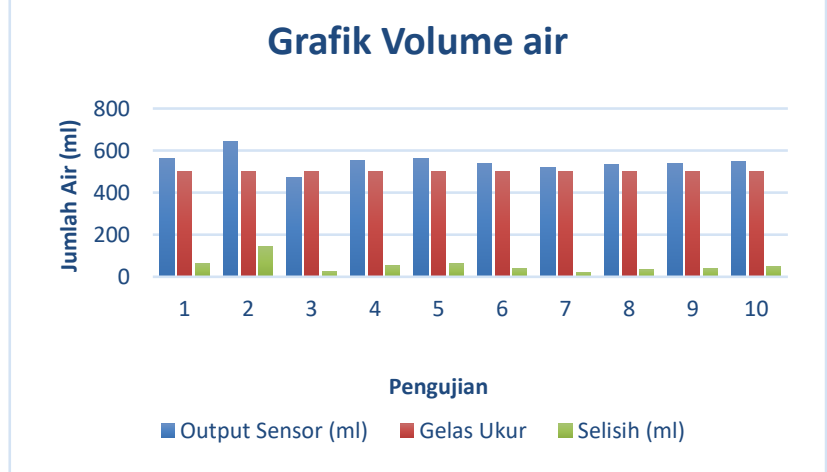

Gbr 8. Grafik Pengujian dengan Nilai Kalibrasi 5.5
Berdasarkan grafik diatas terdapat selisih antara hasil dari waterflow sensor dengan gelas ukur. Berikut ini adalah cara mencari selisih rata rata dari 10 kali percobaan : Selisih rata-rata $=\frac{\text { total selisih }}{\text { jumlah percobaan }}=\frac{530}{10}=53 \mathrm{ml}$

Dan juga didapatkan rata-rata dari Output Sensor $(\mathrm{ml})$ pada $500 \mathrm{ml}$ air dengan menggunakan rumus sebagai berikut:

Rata - rata $=\frac{\text { total Jumlah output sensor }}{\text { jumlah percobaan }}$

$=\frac{5478}{10}=547.8 \mathrm{ml}$

Untuk mencari presentase error pada saat percobaan diatas dengan nilai kalibrasi 5,5 adalah sebagai berikut:

Presenstase Kesalahan

$=\frac{\text { Nilai Yang terukur-Nilai sebenarnya }}{\text { Nilai sebenarnya }} \times 100 \%$

$=\frac{547,8-500}{500} \times 100 \%=9,56 \%$

Tbl 4. Pengujian waterflow sensor dengan nilai kalibrasi 6

\begin{tabular}{ccccc}
\hline $\begin{array}{c}\text { No. } \\
\text { Percobaan }\end{array}$ & $\begin{array}{c}\text { Output } \\
\text { Sensor }(\mathbf{m l})\end{array}$ & $\begin{array}{c}\text { Metode Gelas } \\
\text { Ukur }(\mathbf{m l})\end{array}$ & $\begin{array}{c}\text { Selisih } \\
(\mathbf{m l})\end{array}$ & Kalibrasi \\
\hline $\mathbf{1}$ & $499 \mathrm{ml}$ & $500 \mathrm{ml}$ & $1 \mathrm{ml}$ & 6 \\
\hline $\mathbf{2}$ & $418 \mathrm{ml}$ & $500 \mathrm{ml}$ & $82 \mathrm{ml}$ & 6 \\
\hline $\mathbf{3}$ & $484 \mathrm{ml}$ & $500 \mathrm{ml}$ & $16 \mathrm{ml}$ & 6 \\
\hline $\mathbf{4}$ & $448 \mathrm{ml}$ & $500 \mathrm{ml}$ & $52 \mathrm{ml}$ & 6 \\
\hline $\mathbf{5}$ & $401 \mathrm{ml}$ & $500 \mathrm{ml}$ & $99 \mathrm{ml}$ & 6 \\
\hline $\mathbf{6}$ & $506 \mathrm{ml}$ & $500 \mathrm{ml}$ & $6 \mathrm{ml}$ & 6 \\
\hline $\mathbf{7}$ & $489 \mathrm{ml}$ & $500 \mathrm{ml}$ & $11 \mathrm{ml}$ & 6 \\
\hline $\mathbf{8}$ & $479 \mathrm{ml}$ & $500 \mathrm{ml}$ & $21 \mathrm{ml}$ & 6 \\
\hline $\mathbf{9}$ & $505 \mathrm{ml}$ & $500 \mathrm{ml}$ & $5 \mathrm{ml}$ & 6 \\
\hline $\mathbf{1 0}$ & $509 \mathrm{ml}$ & $500 \mathrm{ml}$ & $9 \mathrm{ml}$ & 6 \\
\hline Total & $4738 \mathrm{ml}$ & & $302 \mathrm{ml}$ & \\
\hline
\end{tabular}

Berdasarkan perbandingan hasil pengujian diatas, maka dibuatlah grafik dari nilai hasil penghujian tersebut.

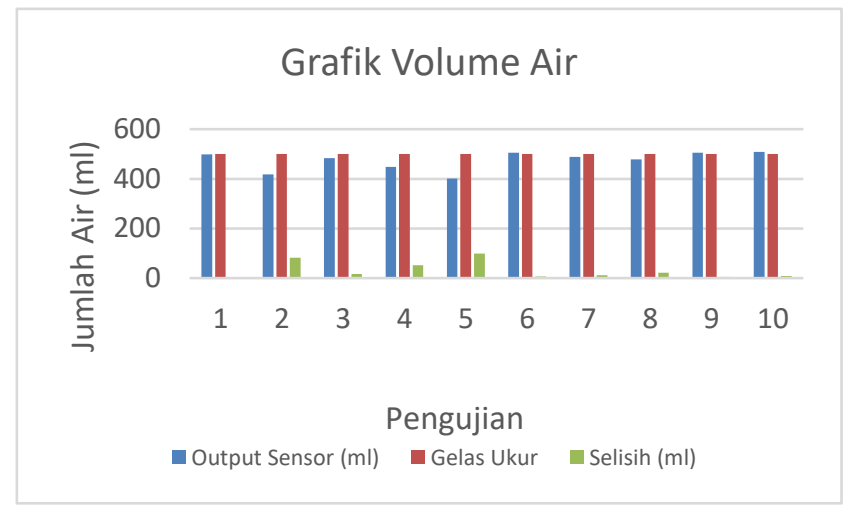

Gbr 9. Grafik Pengujian dengan Kalibrasi 6

Berdasarkan grafik diatas terdapat selisih antara hasil dari waterflow sensor dengan gelas ukur. Berikut ini adalah cara mencari selisih rata rata dari 10 kali percobaan :

Selisih rata-rata $=\frac{\text { total selisih }}{\text { jumlah percobaan }}$ $=\frac{302}{10}=30,2 \mathrm{ml}$

Dan juga didapatkan rata-rata dari Output Sensor $(\mathrm{ml})$ pada $500 \mathrm{ml}$ air dengan menggunakan rumus sebagai berikut

$$
\begin{aligned}
& \text { Rata }- \text { rata }=\frac{\text { total Jumlah output sensor }}{\text { jumlah percobaan }} \\
& =\frac{4738}{10}=473,8 \mathrm{ml}
\end{aligned}
$$


Untuk mencari presentase error pada saat percobaan diatas dengan nilai kalibrasi 6,6 adalah sebagai berikut:

Presenstase Kesalahan

$=\frac{\text { Nilai Yang terukur }- \text { Nilai sebenarnya }}{\text { Nilai sebenarnya }} \times 100 \%$

$=\frac{500-473,8}{500} \times 100 \%=5,24 \%$

\begin{tabular}{ccccc} 
Tbl 5. & \multicolumn{4}{c}{ Pengujian waterflow sensor dengan nilai kalibrasi 6.7 } \\
\hline $\begin{array}{c}\text { No. } \\
\text { Percobaan }\end{array}$ & $\begin{array}{c}\text { Output } \\
\text { Sensor }(\mathbf{m l})\end{array}$ & $\begin{array}{c}\text { Metode Gelas } \\
\text { Ukur }(\mathbf{m l})\end{array}$ & $\begin{array}{c}\text { Selisih } \\
(\mathbf{m l})\end{array}$ & $\begin{array}{c}\text { Kalibrasi } \\
\text { Faktor }\end{array}$ \\
\hline $\mathbf{1}$ & $508 \mathrm{ml}$ & $500 \mathrm{ml}$ & $8 \mathrm{ml}$ & 6.7 \\
\hline $\mathbf{2}$ & $509 \mathrm{ml}$ & $500 \mathrm{ml}$ & $9 \mathrm{ml}$ & 6.7 \\
\hline $\mathbf{3}$ & $506 \mathrm{ml}$ & $500 \mathrm{ml}$ & $6 \mathrm{ml}$ & 6.7 \\
\hline $\mathbf{4}$ & $505 \mathrm{ml}$ & $500 \mathrm{ml}$ & $5 \mathrm{ml}$ & 6.7 \\
\hline $\mathbf{5}$ & $504 \mathrm{ml}$ & $500 \mathrm{ml}$ & $4 \mathrm{ml}$ & 6.7 \\
\hline $\mathbf{6}$ & $508 \mathrm{ml}$ & $500 \mathrm{ml}$ & $8 \mathrm{ml}$ & 6.7 \\
\hline $\mathbf{7}$ & $494 \mathrm{ml}$ & $500 \mathrm{ml}$ & $6 \mathrm{ml}$ & 6.7 \\
\hline $\mathbf{8}$ & $499 \mathrm{ml}$ & $500 \mathrm{ml}$ & $1 \mathrm{ml}$ & 6.7 \\
\hline $\mathbf{9}$ & $514 \mathrm{ml}$ & $500 \mathrm{ml}$ & $14 \mathrm{ml}$ & 6.7 \\
\hline $\mathbf{1 0}$ & $495 \mathrm{ml}$ & $500 \mathrm{ml}$ & $5 \mathrm{ml}$ & 6.7 \\
\hline & & Total Selisih $=$ & $66 \mathrm{ml}$ &
\end{tabular}

B. Berdasarkan perbandingan hasil pengujian diatas, maka dibuatlah grafik dari nilai hasil penghujian tersebut.

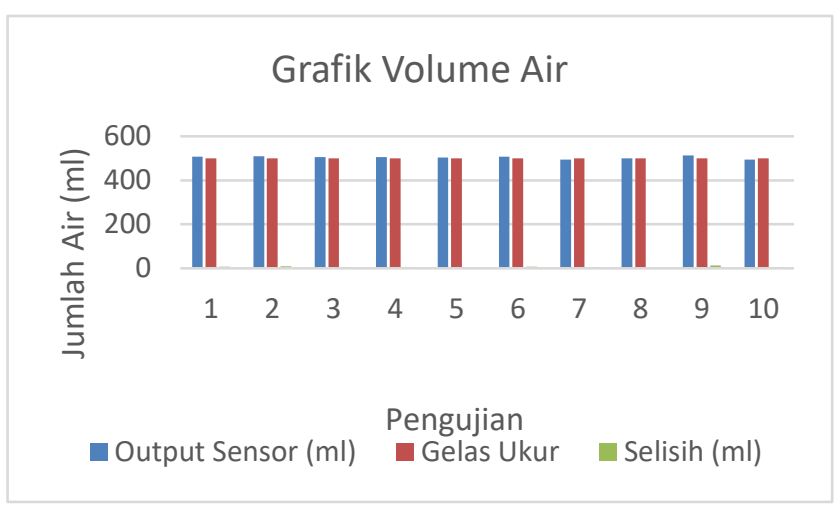

Gbr 10. Grafik Pengujian dengan Kalibrasi 6,7

Berdasarkan grafik diatas terdapat selisih antara hasil dari waterflow sensor dengan gelas ukur. Berikut ini adalah cara mencari selisih rata rata dari 10 kali percobaan :

Selisih rata-rata $=\frac{\text { total } \text { selisih }}{\text { jumlah percobaan }}=\frac{66}{10}=6.6 \mathrm{ml}$

Dan juga didapatkan rata-rata dari Output Sensor $(\mathrm{ml})$ pada $500 \mathrm{ml}$ air dengan menggunakan rumus sebagai berikut:

$$
\begin{aligned}
\text { Rata }- \text { rata } & =\frac{\text { total Jumlah output sensor }}{\text { jumlah percobaan }} \\
& =\frac{5042}{10}=504.2 \mathrm{ml}
\end{aligned}
$$

Untuk mencari presentase error pada saat percobaan diatas dengan nilai kalibrasi 6,6 adalah sebagai berikut:

Presenstase Kesalahan

$\frac{\text { Nilai Yang terukur-Nilai sebenarnya }}{\text { Nilai }}$ 100\%

$=\frac{504,2-500}{500} \times 100 \%=0,84 \%$

\section{Pengujian Modul RTC DS 1307}

Berikut ini perbandingan hasil dari modul RTC DS1307 yang akan ditampilkan ke dalam serial monitor arduino, waktu di PC dan Smartphone.

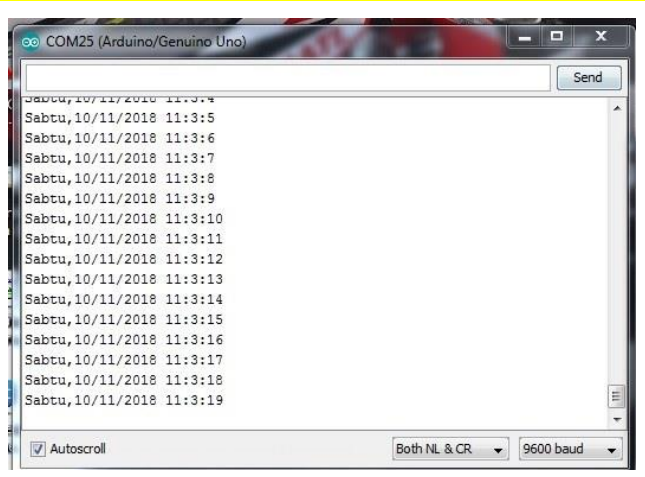

Gbr 11. Tampilan pada Serial Monitor

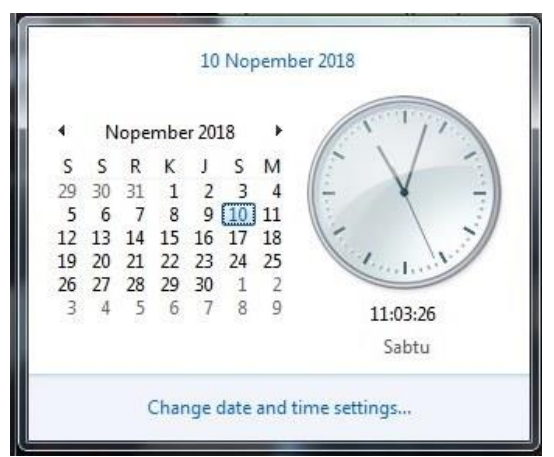

Gbr 12.

Tampilan Waktu pada PC

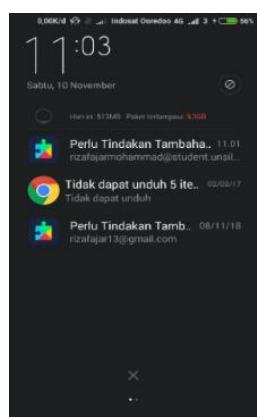

Gbr 13. Tampilan Waktu pada Smartphone

Pada pengujian yang kedua yaitu dengan pengujian pada baterai cadangan RTC DS1307. Pengujian yang kedua ini, arduino uno akan diputuskan dari catu daya.

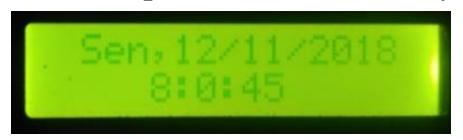

a. Sebelum Dimatikan

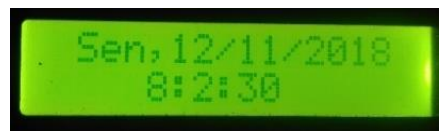

b. Sesudah Dinyalakan

Gbr 14. Tampilan Jam dan Tanggal Sebelum dan Setelah Dimatikan

\section{Pengujian Buzzer}

Berikut ini adalah hasil pengujian saat tanggal dan waktu telah ditentukan.

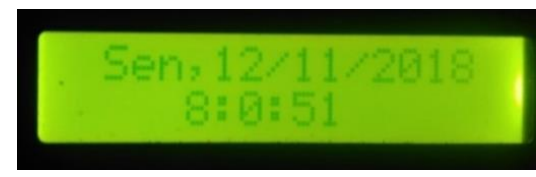

Gbr 15. Kondisi Waktu Yang Telah Ditentukan 


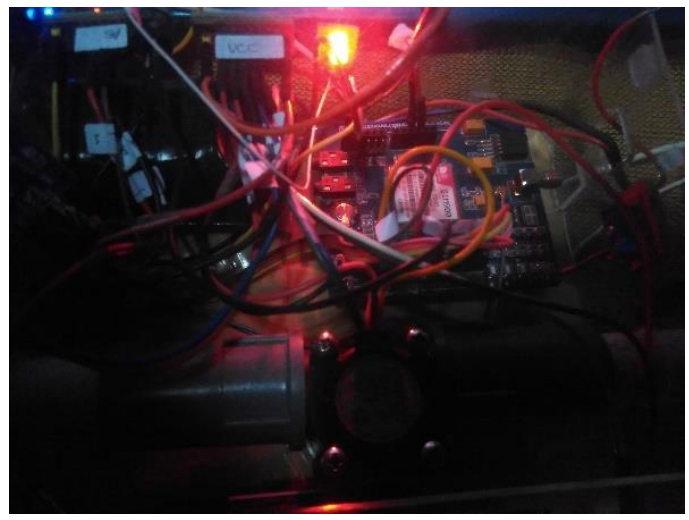

Gbr 16. Kondisi Buzzer Saat Menyala

Tbl 6. Hasil Pengujian Buzzer

\begin{tabular}{cccc}
\hline No & Tanggal \& Waktu & Buzzer & Bunyi \\
\hline $\mathbf{1}$ & $12 / 11 / 2018,8: 0: 51$ & High & On \\
\hline $\mathbf{2}$ & $12 / 11 / 2018,8: 1: 21$ & Low & Off \\
\hline $\mathbf{3}$ & $12 / 11 / 2018,8: 5: 42$ & High & On \\
\hline $\mathbf{4}$ & $12 / 11 / 2018,8: 6: 12$ & Low & Off \\
\hline $\mathbf{5}$ & $12 / 11 / 2018,8: 10: 31$ & High & On \\
\hline
\end{tabular}

\section{E. Pengujian Modul Sim 900}

Pengujian konektivitas SIM900 dimaksudkan untuk mengetahui tingkat keberhasilan transmisi data ke webserver. Berikut adalah hasil pengujian sim900 dengan webserver thingspeak.

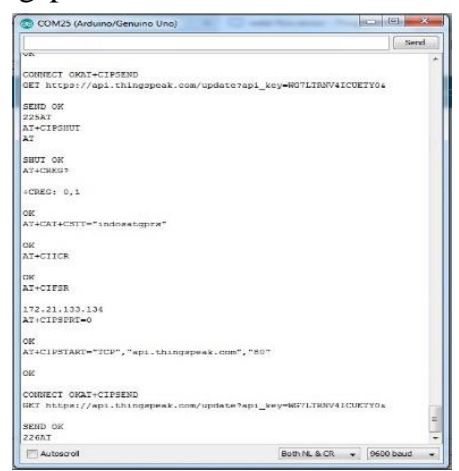

Gbr 17. Proses Koneksi Sim900 Dengan Webserver Thingspeak

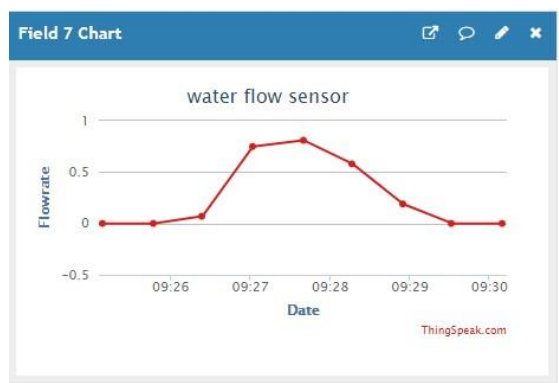

Gbr 18. Hasil Pengujian Modul Sim900 dengan webserver thingspeak pada PC

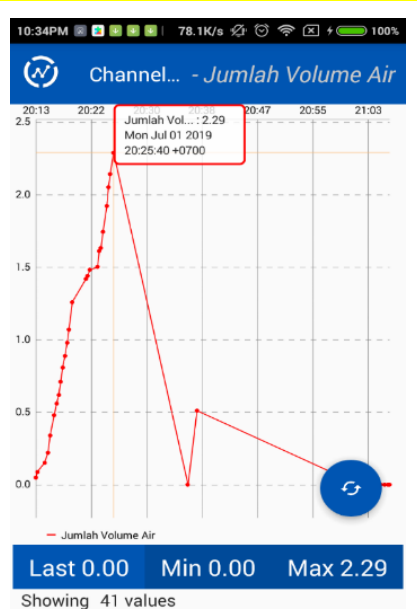

Gbr 19. Hasil Pengujian Modul Sim900 dengan webserver thingspeak pada Aplikasi Android

\section{F. Pengujian Baterai Tanpa Solar Cell}

Pengujian ini dimaksudkan untuk mengetahui daya tahan baterai pada saat dibebani oleh arduino uno dan komponen lainnya tanpa adanya charging dari solar cell. Berikut ini pengujian baterai lithium ion tanpa solar cell :

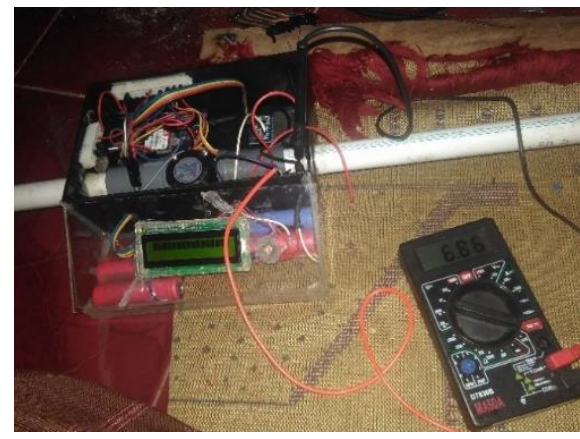

Gbr 20. Pengujian Baterai Tanpa Solar Cell

Tbl 7. Pengujian Daya Tahan Baterai Lithium Ion Tanpa Solar Cell

\begin{tabular}{cc}
\hline Waktu (menit) & Tegangan (v) \\
\hline $\mathbf{0}$ & 7,4 \\
\hline $\mathbf{5}$ & 7,4 \\
\hline $\mathbf{1 0}$ & 7,4 \\
\hline $\mathbf{1 5}$ & 7,4 \\
\hline $\mathbf{2 0}$ & 7,4 \\
\hline $\mathbf{2 5}$ & 7,4 \\
\hline $\mathbf{4 0}$ & 7,39 \\
\hline $\mathbf{5 2}$ & 7,38 \\
\hline $\mathbf{6 0}$ & 7,37
\end{tabular}

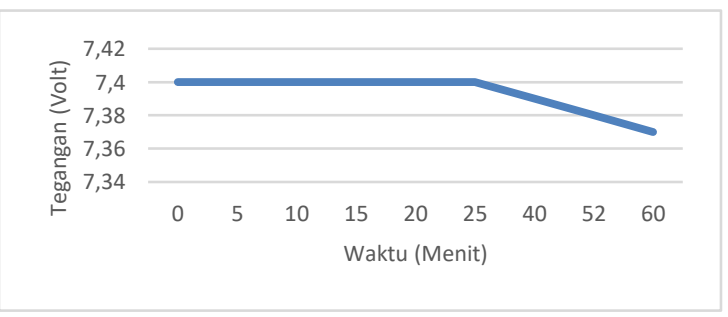

Gbr 21. Grafik Pengujian Baterai

Berikut ini hasil pengukuran dari semua komponen arduino uno dengan kondisi backlight LCD tidak menyala 
didapat arus sebesar $106 \mathrm{~mA}$ dengan tegangan baterai 7.4 Volt, maka daya yang dikonsumsinya sebagai berikut :

\section{$\mathbf{P}=\mathbf{V} \times \mathbf{I}$}

\section{Dimana :}

$\mathbf{P}=$ Daya Listrik dengan satuan Watt (W)

$\mathrm{V}=$ Tegangan Listrik $(\mathrm{V})$

$\mathrm{I}=\operatorname{Arus} \operatorname{Listrik}(\mathrm{A})$

$$
\begin{aligned}
& \mathbf{P}=\mathbf{V} \times \mathbf{I} \\
& =7.4 \mathrm{~V} \times 0,106 \mathrm{~A} \\
& =0,784 \mathrm{~W}
\end{aligned}
$$

Kemudian daya yang dihasilkan baterai dengan kapasitas $4400 \mathrm{mAh}$ dan 7,4 Volt ini, maka daya yang dihasilkan sebagai berikut :

$$
\begin{aligned}
& \mathbf{P}=\mathbf{V} \mathbf{x} \mathbf{I} \\
& =7,4 \mathrm{~V} \times 4,4 \mathrm{~A} \\
& =32,56 \mathrm{~W}
\end{aligned}
$$

Maka daya tahan baterainya sebagai berikut :

$$
\mathrm{T}=\frac{\text { PBaterai }}{\text { PBeban }}
$$

Dimana

$$
\begin{aligned}
& \text { T = Waktu Pembebanan }(\mathrm{h}) \\
& \text { Pbaterai = Daya Baterai }(\mathrm{Wh}) \\
& \text { Pbeban = Daya Beban }(\mathrm{W})
\end{aligned}
$$

$$
\mathrm{T}=\frac{32 \mathrm{Wh}}{0,784}=40,81 \mathrm{~h}
$$
detik.

Jadi daya tahan baterainya hingga 40 jam 48 menit 36

\section{G. Pengujian Ketepatan Data}

Pengujian ketepatan data ini dilakukan untuk mengetahui kinerja antara perangkat keras dan perangkat lunak guna mendapatkan data yang tepat.

\section{H. Pengujian Ketepatan Data pada Webserver Thingspeak dengan $L C D$}

Pengujian ini dilakukan dengan cara login terlebih dahulu pada website thingspeak. Selanjutnya setelah berhasil login, maka website thingspeak akan menampilkan beberapa grafik seperti flowrate, tarif tagihan, Volume air dan tegangan baterai. Setelah itu nanti akan dibandingan antara hasil pada LCD dan dengan website thingspeak. Berikut ini hasil pengujian ketepatan data yang diterima oleh webserver thingspeak :

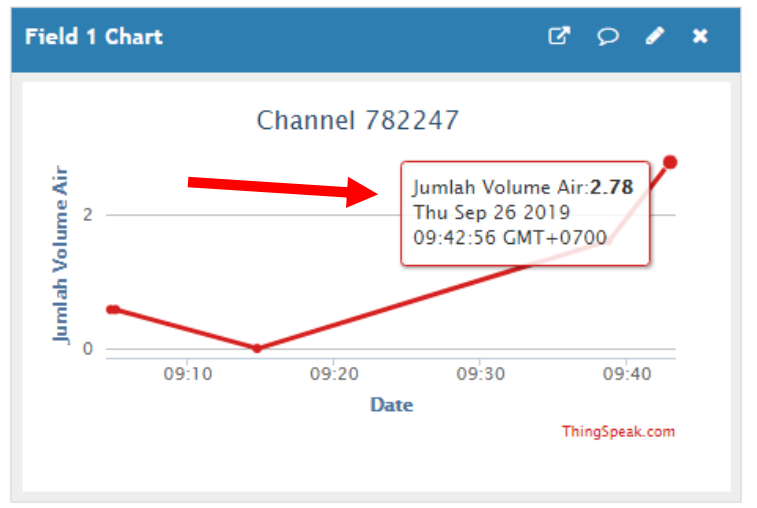

Gbr 22. Grafik Volume Air Pada Web Server

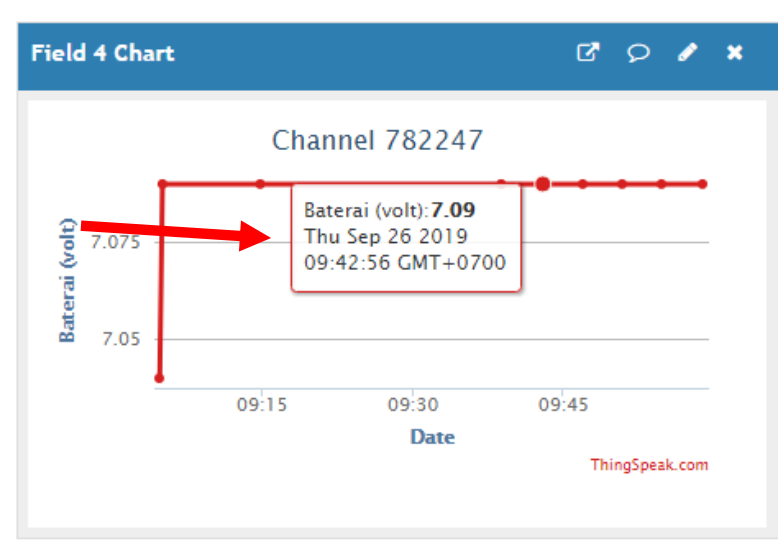

Gbr 23. Grafik Tegangan Baterai Pada Web Server

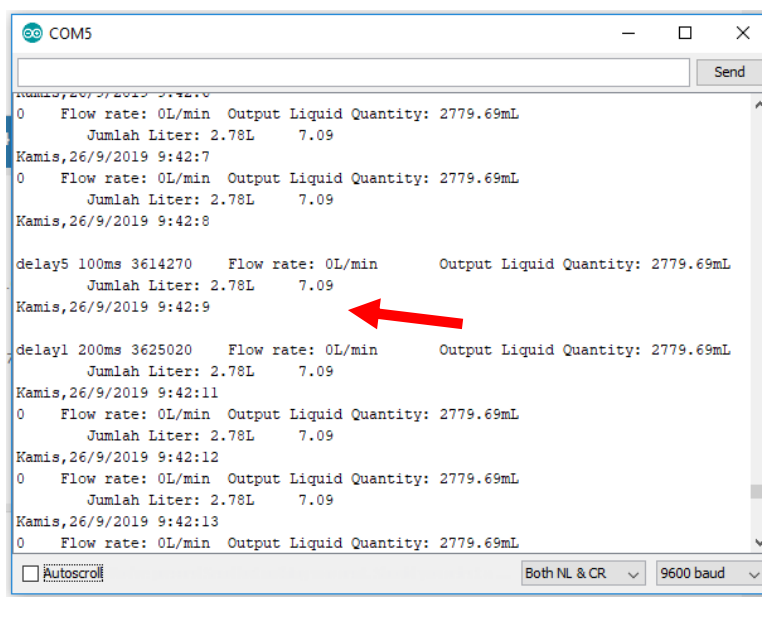

Gbr 24. Serial Monitor Pada IDE arduino

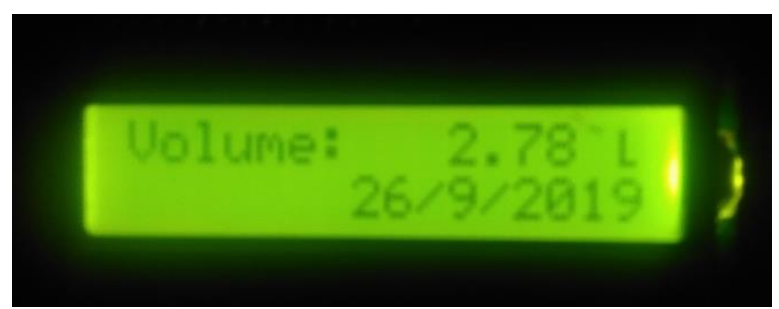

Gbr 25. Pengujian Ketepatan Data Pada LCD

Setelah melakukan pengujian dengan cara mengaliri air pada saluran pipa yang terhubung dengan waterflow sensor, maka hasil dari pengujian ini sesuai antara webserver thingspeak dengan tampilan pada LCD, yaitu sebanyak $2.78 \mathrm{~L}$.

I. Pengujian Ketepatan Data Secara Manual

Dalam pengujian ini dilakukan dengan cara mengalirkan air sebanyak 5 liter yang terdapat pada tabung yang nantinya air akan mengalir pada pipa 1/2", maka diperolehlah waktu : 


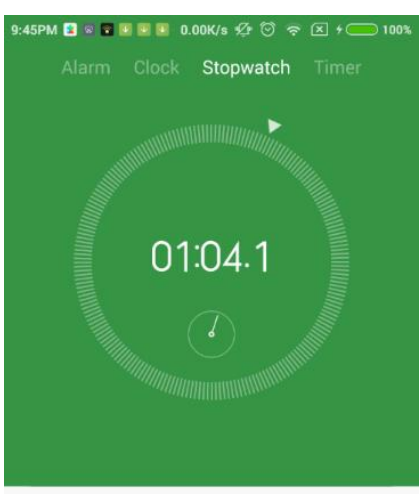

Gbr 26. Waktu Yang Diperoleh

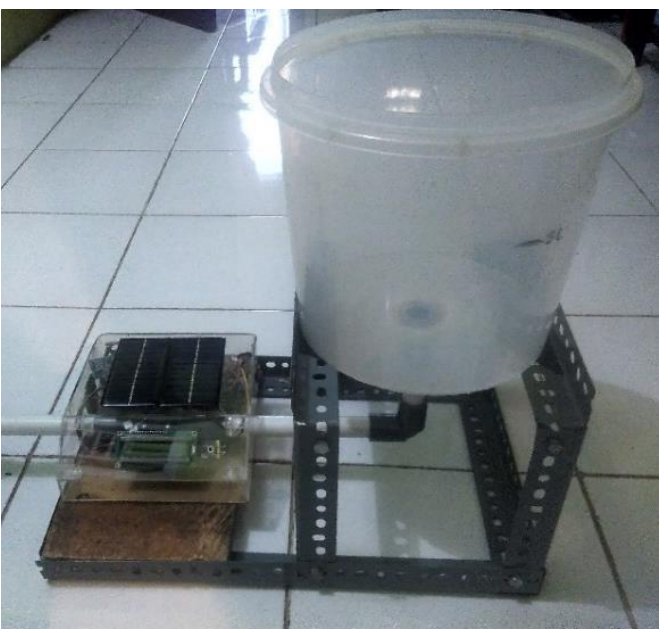

Gbr 27. Proses Pengujian Ketepatan Data

Setelah melakukan pengujian dengan mengaliri air sebanyak 5 L dengan menggunakan pipa 1/2", maka didapat waktu 1 menit 4 detik.

Berikut ini cara mengetahui debit air yang mengalir pada pipa $1 / 2 "$ :

$$
\begin{aligned}
\mathrm{Q} & =\frac{V}{t} \\
& =\frac{5}{64}=0,078 \mathrm{l} / \mathrm{s}
\end{aligned}
$$

\section{J. Pengujian Sistem Keseluruhan}

Berikut ini adalah hasil pengujian keseluruhan sistem dengan asumsi 1 kali percobaan sama dengan 1 hari. Dalam pengujian ini diuji sebanyak 7 kali percobaan:

Tbl 8. Hasil Pengujian Sistem Keseluruhan

\begin{tabular}{ccccccc}
\hline No & $\begin{array}{c}\text { Quantity } \\
(\mathbf{L})\end{array}$ & Tanggal & Jam & Status & $\begin{array}{c}\text { Baterai } \\
(\mathbf{V})\end{array}$ & $\begin{array}{c}\text { Buzzer } \\
\text { LED }\end{array}$ \\
\hline $\mathbf{1}$ & 0 & 26-Sep-19 & $9: 14: 48$ & Terkirim & 7,09 & Off \\
\hline $\mathbf{2}$ & 1,61 & 26-Sep-19 & $9: 38: 47$ & Terkirim & 7,09 & Off \\
\hline $\mathbf{3}$ & 2,78 & $26-$ Sep-19 & $9: 42: 56$ & Terkirim & 7,09 & Off \\
\hline $\mathbf{4}$ & 4,72 & $26-$ Sep-19 & $9: 46: 56$ & Terkirim & 7,09 & ON \\
\hline $\mathbf{5}$ & 5,73 & 26-Sep-19 & $9: 50: 53$ & Terkirim & 7,09 & Off \\
\hline $\mathbf{6}$ & 8,86 & 26-Sep-19 & $9: 54: 47$ & Terkirim & 7,09 & Off \\
\hline $\mathbf{7}$ & 10,41 & 26-Sep-19 & $9.58: 56$ & Terkirim & 7,09 & Off
\end{tabular}

Dari hasil pengujian keseluruhan ini terdapat 7 kali percobaan, dimana hasil dari 7 kali percobaan tersebut sistem bekerja denga baik. Dimulai dari tanggal, waktu sesuai dengan RTC dan waktu pada komputer. Buzzer dan Led aktif ketika 26-Sep-19 jam 9:42:56. Dari 7 kali percobaan tersebut volume air dan tegangan baterai semuanya terkirim dengan baik tanpa adanya data yang tidak terkirim. Hanya saja terdapat kekurangan yaitu thingspeak hanya mampu update data setiap 15 detik sekali.

\section{K. Analisa Data}

Dari beberapa kali percobaan yang dilakukan diatas dapat diambil analisa bawah setelah melakukan kalibrasi, air yang mengalir dari penampung air sebanyak $500 \mathrm{ml}$ dengan nilai kalibrasi 6,7 diperoleh nilai rata rata jumlah air yang mengalir sebesar $504.2 \mathrm{ml}$ dengan menunjukan hasil error sebesar $0,84 \%$ dan selisih rata - rata sebesar $6.6 \mathrm{ml}$. Nilai kalibrasi 6 diperoleh nilai rata rata jumlah air yang mengalir sebesar 473,8 ml dengan menunjukan hasil error sebesar $5,24 \%$ dan selisih rata - rata sebesar $32 \mathrm{ml}$. Nilai kalibrasi 5.5 diperoleh nilai rata rata jumlah air yang mengalir sebesar dengan menunjukan hasil error sebesar 9,56\% dan selisih rata - rata sebesar $53 \mathrm{ml}$. Keadaan error seperti ini akan terus terjadi setiap kali pengukuran yang dilakukan seperti terlihat pada lampiran. Error yang terjadi juga tidak akan tetap atau berubah-ubah tergantung dengan nilai kalibrasi yang telah ditentukan di awal. Bukan hanya itu, besarnya tekanan, kecepatan air juga mempengaruhi hasil pengukuran. Semakin banyak melakukan percobaan maka semakin kecil presentase error yang akan didapatkan.

Dari percobaan koneksi SIM900 dengan webserver thingspeak diatas dapat diambil analisa bahwa setelah melakukan pengujian sebanyak 7 kali percobaan, data yang terkirim ke webserver thingspeak terkirim dengan baik tanpa adanya gangguan sama sekali. Rata-rata waktu pengiriman data ke webserver thingspeak sebesar 15 detik/data. Perbedaan waktu pengiriman data ke webserver thingspeak tersebut diakibatkan oleh proses koneksi antara SIM900 dengan webserver thingspeak. Sedangkan Thingspeak hanya mempunyai kemampuan mengupdate data sebesar $15 \mathrm{~s} /$ data.

Dari pengujian baterai tanpa charger dari solar cell menunjukan hubungan yang berbanding lurus antara konsumsi daya pada arduino dengan daya tahan baterai. Semakin kecil konsumsi daya yang digunakan maka lifetime baterai semakin tahan lama. Pengurangan tegangan baterai diperoleh sebesar $0,05 \mathrm{~V}$ setelah digunakan 1 jam.

Dari pengujian pengisian baterai menunjukan hubungan yang sebanding lurus antara arus dengan kecepatan pengisian baterai. Semakin besar arus yang diterima baterai maka semakin cepat baterai melakukan pengisian. Saat pengisian diperoleh arus sebesar 0,4 A dengan lama pengisian 13 jam.

Dari pengujian buzzer Alarm pengingat tagihan konsumen berbunyi sesuai waktu yang telah ditentukan sebelumnya yaitu pada tanggal 26-Sep-19 jam 9:46:56. Semakin detail waktu yang ditentukan maka semakin tepat buzzer menyala.

\section{KESIMPULAN}

Berdasarkan hasil pembuatan alat, pengujian dan Analisa alat, maka dapat diambil kesimpulan dari penulisan laporan ini. Adapun kesimpulannya adalah Hasil dari konfigurasi alat menunjukan rata rata jumlah selisih air pada saat percobaan $500 \mathrm{ml}$ air dengan nilai kalibrasi 6,7 adalah 6.6 ml. Untuk percobaan $500 \mathrm{ml}$ air dengan nilai kalibrasi 6 didapatkan rata rata selisih air sebesar 30,2 $\mathrm{ml}$ dan percobaan $500 \mathrm{ml}$ air dengan nilai kalibrasi 5,5 didapatkan rata rata selisih air sebesar $53 \mathrm{ml}$. Untuk mendapatkan presentase error yang kecil maka Diperlukan pengujian sebanyak mungkin untuk mendapatkan hasil yang sesuai dengan alat ukur.. 
SIM900 GPRS shield modul berhasil mengirim data sensor ke webserver thingspeak tanpa adanya gangguan koneksi. Hasil dari display thingspeak sesuai dengan tampilan display LCD.

Baterai dengan tegangan 7.4 Volt 4400 mAh bisa bertahan selama 40 jam 48 menit 36 detik dalam kondisi backlight LCD mati. Untuk mendapatkan life time yang lebih lama diperlukan penambahan kapasitas baterai.

Dengan dirancangnya alat ini diharapkan pelanggan PDAM dapat memantau penggunaan air melalui interface webiste thingspeak dan aplikasi android.

\section{REFERENSI}

[1] Sean Setya Henura, Triyogatama Widodo Wahyu. 2015. Rancang Bangun Sistem Jaringan Nirkabel Untuk Pemantauan Konsumsi Air Pelanggan PDAM” Universitas Gajah Mada. Tersedia: http://journal.ugm.ac.id/ijeis/article/view/7639/5922

[2] P. D. Rebiyanto and A. Rofii, "Universitas 17 Agustus 1945 Jakarta," vol. 2, no. 2, p. Jamur, Otomatis, Suhu, Kelembaban, Internet of Thi, 2016.

[3] Erick Sorongan, Qory Hidayati, Kuat Priyono 2018. Thingspeak Sebagai Sistem Monitoring Tangki Spbu Berbasis Internet Of Things tersedia: https://jtera.polteksmi.ac.id/index.php/jtera/article/vie w/121.

[4] Thowil Afif M.2015. Analisis Perbandingan Baterai Lithium-Ion, Lithium-Polymer, Lead Acid Dan NickelMetal Hydride Pada Penggunaan Mobil Listrik Review. Rekayasa Mesin. 6(2):95-99.

\section{BIOGRAFI PENULIS}

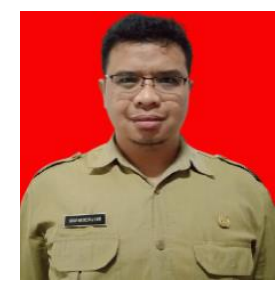

Nidar Nadrotan Naim, lahir di Tasik pada tanggal 25 Januari 1983, saat ini bertugas sebagai staf pengajar di Jurusan Teknik Elektro, Universitas Siliwangi, bidang penelitian yang ditekuni saat ini adalah renewable energy dan IoT.

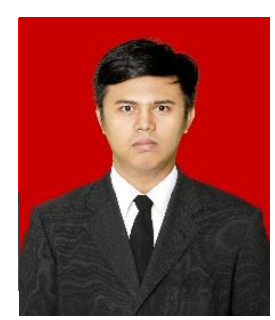

Imam Taufiqurrahman, lahir di Bandung pada tanggal 12 juni 1990, saai ini bertugas sebagai staf pengajar di Jurusan Teknik Elektro, Universitas Siliwangi, bidang penelitian yang ditekuni saat ini adalah Otomasi, Robotika dan Sistem Cerdas. 